\section{Private Universities in a Public Framework: The Italian Experience}

\section{FIONA HUNTER}

Fiona Hunter is the international director at the Università Carlo CattaneoLIUC in Italy. E-mail: fhunter@liuc.it.

$\mathrm{I}_{\mathrm{c}}^{\mathrm{n}}$ n contrast to the worldwide explosion in private higher eduI cation provision, the private sector in western Europe has essentially remained a peripheral one that has not attracted the attention of researchers. The attempts to describe private provision in the emerging body of literature highlight its heterogeneous nature, for while expansion involves a global trend, much variation occurs in state stance and policy and in the nature and purpose of emerging private higher education. In the current debate on the privatization of public higher education, private universities operating within a public system become interesting cases for analysis. The term "private" in this article refers exclusively to "nonstate" or "free" higher education institutions operating within the Italian regulatory framework as nonprofit organizations.

\section{EMERGENCE AND EXPANSION}

The persistence of a highly centralized and uniform model of higher education, established at the time of Italian unification, has resisted societal pressures for decentralization and diversification. The Italian Constitution nevertheless provides the conditions for private provision, and alongside 6r state universities there are currently 28 nonstate universities. While the nonstate institutions represent over 25 percent of the sector, they are significantly smaller in terms of enrollment, with around Io percent of the total student population. The vast majority of the nonstate institutions have come into being in recent decades in response to growth and variety in demand only partially met by the state. Private expansion has occurred alongside public expansion.

The 2oth century experienced the birth and intermittent development of the nonstate sector. Until i990 there were only 7 private universities, but between I990 and 2000 a further 6 were founded. Since 2000, I5 more institutions have come into existence, II of which are distance-education providers set up since 2004. Another phenomenon is the transformation from private to public status of nonstate universities unable to meet the challenges of expansion and rising costs. The increasing financial pressure of this trend on the higher education budget forced the state to reconsider its laissez-faire policy toward spontaneous growth of the sector. Likewise, all new requests, whether private or public, must be authorized within a central development plan.

\section{State Regulatory Framework}

A private university initiative seeking to obtain recognition from the Ministry for Education, Universities and Research needs to demonstrate adequate infrastructure, academic resources, and financial capital. After obtaining the legal right of operation as a nonprofit organization, the unit's degrees must be approved and granted legal validity, awarding them equal status with the state sector. While state recognition brings legitimation, it also restricts autonomy by imposing extensive legislative requirements in curricular content, credit weighting, and academic ratios as well as quality assurance standards and performance measurements on a par with the state sector.

While nonstate universities are governed to a large extent by the national regulatory framework, they remain essentially self-funding institutions, relying almost exclusively on income derived from tuition. In recognition of their public service, they receive a small contribution from the state higher education budget that averages at around I4 percent. Universities supported by local authorities or that offer healthcare through their medical centers will receive a higher proportion of public funds, and those with strong affiliation to a stakeholder community may have access to funding via donations or endowments. They compete on a par with the state universities in bid processes for research funds.

The nonstate universities have less financial accountability by virtue of their funding structure but are bound by national legislation for the hiring of tenured academics, and tend to keep numbers low to reduce fixed costs and enhance flexibility. Tenured staff in nonstate universities represent around 5 percent of the national total, with significant sharing of the academic workforce through the use of contracted staff from the public sector. These universities enjoy greater autonomy in the recruitment of administrative and nontenured academic staff and are independent in the acquisition and maintenance of physical plant. Their internal governance arrangements have more extensive external stakeholder involvement, and decision-making structures are typically more accountable to their sponsoring institutions.

The Italian nonstate sector is heavily regulated through the requirements for legal validity, and its "privateness" or degree of discretionary behavior is significantly reduced, with only minor margins of greater autonomy than the state sector. The Italian stance to private higher education is one of incorporation through a process of standard accreditation to ensure quality across the system but without an equal distribution of funding. As a consequence, the nonstate sector has not brought significant diversity with most institutions coming into being according to a model of "more" or "better" education.

\section{Institutional Profiles}

While its educational model may not be highly distinctive, the nonstate sector has flourished over the last 20 years, and insti- 
tutional profiles demonstrate variety in age, size, location, academic configuration, ownership, and reputation. For example, the Catholic University of the Sacred Heart is a large, wellestablished multicampus and multifaculty institution offering all three educational cycles and full research facilities. While it has over 40,000 students and I,400 tenured staff, the other, much smaller, nonstate universities have only a few hundred students and a handful of staff offering a limited range of education and research services, such as the highly specialized University of Gastronomic Sciences. There is a wide range of disciplines across the sector (including medicine).

\section{In contrast to the worldwide explosion in private} higher education provision, the private sector in western Europe has essentially remained a peripheral one that has not attracted the attention of researchers.

While the nonstate universities are based predominantly in the north and center of Italy, with over half of the universities close to or in Rome and Milan, nevertheless a wide geographic spread exists across the country. The profiles of the institutions are also influenced by the different types of ownership that fall into three broad categories: religious (Roman Catholic) ownership or affiliation, local authority institutions, and business groups or individuals (including the recently founded distance-education providers). These categories influence their focus of mission, disciplines, and target groups.

With diversity of reputation, many nonstate universities place emphasis on academic excellence and are well-respected. Yet, some of the more recently established universities are considered less trustworthy, and their ability to meet minimum operational and financial requirements have been questioned both by the sector and the state.

\section{CONCLUSION}

The regulatory framework has traditionally focused on centralization and uniformity, which has led to the emergence of an essentially analogous private sector with a strong sense of public mission alongside service to a specific stakeholder community. It remains peripheral despite significant expansion in recent years in response to growth and variety of demand. Italian nonstate universities are hybrid institutions, accountable to both state and market. Precisely because they are forced to ensure their own financial sustainability, the new conditions of a more competitive international environment should be more conducive to their development. The author's recent study of three nonstate universities suggested that international and national market pressures are contrasting the power of the state in determining the environment and playing a stronger role in defining institutional direction. As the divide between private and public higher education blurs, Italian nonstate universities successful in exploiting their "privateness" have the potential to become examples of best practice.

\section{Central Asia: Increasing Diversity}

\section{Martha Merrill}

Martha Merrill is associate professor of higher education at Kent State University. She worked on university reform in Kyrgyzstan from 1996 to 2001. E-mail: mmerril@kent.edu.

A lthough Central Asian nations are linked geographically and historically, their higher education systems are following different paths. The five countries-Kazakhstan, Kyrgyzstan, Tajikistan, Turkmenistan, and Uzbekistan-even at the time of the Soviet Union's dissolution varied in wealth, natural resources, population size, geography, government control, languages spoken, treatment of nontitular ethnic groups, and existing higher education resources. Since then, they have addressed nation building and the creation of professional elites in different ways and with varied resources and philosophies.

\section{A Clear Example}

In August 2009, the most repressive country, Turkmenistan, prevented students from traveling to Kyrgyzstan, the country with the region's most diverse system of higher education, even physically removing them from airplanes. The focus of Turkmenistan's wrath was the American University of Central Asia, a locally founded university with Kyrgyzstani licensure and attestation. However, it appeared that the more than 60 students who were refused access to that institution would be allowed to attend the American University of Bulgaria, which has both US and Bulgarian accreditation. However, in early October, Turkmen authorities prohibited students from flying to Bulgaria. Currently, rumors say they will be enrolled in Russian universities.

\section{TURKMENISTAN-ONE EXTREME}

Turkmenistan is at one end of the continuum of diversity, choice, and academic freedom. Its dictator, Sapramurat Niyazov, who died in December 2006, cut higher education from 5 years to 2 and secondary education from II years to 9; closed the Academy of Sciences and most libraries, and required that hours of class time be devoted to the 